\title{
Supplemetary Figure
}
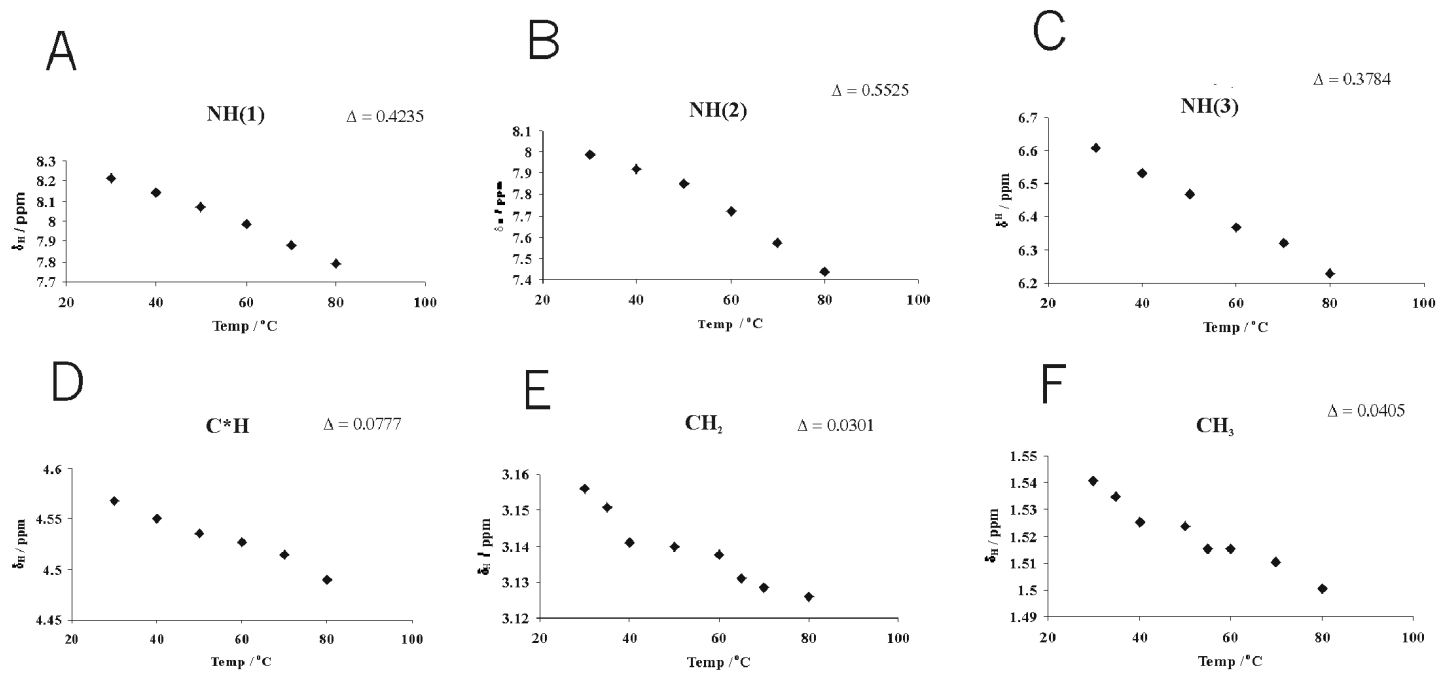

Figure a. Effect of temperature on the resonances of different functional groups present in the dendritic branch, [dendritic branch] = 20mM, [C9] = 10mM. (a) $\mathrm{NH}$ (1) (amide); (b) $\mathrm{NH}(2$ ) (amide); (c) $\mathrm{NH}(3)$ (carbamate); (d) $\mathrm{C}^{*} \mathrm{H}$ [proton at chiral centre]; (e) $\mathrm{CH}_{2} \mathrm{NH}$; (f) $\mathrm{CH}_{3}$ 